\title{
PERAN DINAS PARIWISATA DAN KEBUDAYAAN DALAM UPAYA PELESTARIAN KESENIAN BUDAYA LOKAL
}

\author{
Fitriana $^{1}$, Yusuf Adam Hilman ${ }^{2}$, Bambang Triono ${ }^{3}$ \\ ${ }^{1}$ Fakultas Ilmu Sosial dan Ilmu Politik, Universitas Muhammadiyah Ponorogo \\ korespondensi email: fitriumpo@gmail.com \\ ${ }^{2}$ Fakultas Ilmu Sosial dan Ilmu Politik, Universitas Muhammadiyah Ponorogo \\ email: 54547aadamongis@gmail.com \\ ${ }^{3}$ Fakultas Ilmu Sosial dan Ilmu Politik, Universitas Muhammadiyah Ponorogo \\ email: bambangtriono@umpo.ac.id
}

\begin{abstract}
This report aims to review the role of done by of tourism and culture Ponorogo Regency effort in preserving local culture and local art, Also, to know what just working in the opposite direction as well as supporters of the implementation of the preserving. This is a descriptive qualitative research methodology, by gathering data interviews and documentation. The result of this study tourism agency role in improving the local Ponorogo Regency, culture namely by conducting routine, the festival to the community, socialization the development of their talent interest, young generation and the introduction of culture to other regions. Of the activity will impact the increase in the group of the arts which every year is increasing and stable, it has been achieved due to the efforts of the office of tourism and culture Ponorogo Regency who honored consistently. Also, the introduction of the local culture outside the region attracts tourists from the outside to visit Ponorogo Regency routine performances to see a title particularly Reyog Ponorogo. national festival. But efforts have done there are several local arts in the extract of the agency data decrease the number of people interested and the less. even necessary to special handling.
\end{abstract}

Keyword: tourism; preservation of art; local cultural.

\begin{abstract}
ABSTRAK
Penelitian ini bertujuan untuk mengetahui peran yang dilakukan oleh Dinas Pariwisata dan Kebudayaan Kabupaten Ponorogo dalam upaya melestarikan kebudayaan lokal serta kesenian lokal, selain itu ingin mengetahui apa saja yang menjadi penghambat serta pendukung dari pelaksanaan upaya pelestarian tersebut. Metode penelitian ini adalah deskriptif kualitatif, dengan mengumpulkan data hasil wawancara dan juga dokumentasi, Hasil dari penelitian ini Dinas pariwisata berperan dalam meningkatkan potensi kebudayaan lokal Kabupaten Ponorogo, yaitu dengan cara melakukan kegiatan festival rutin, sosialisai kepada masyarakat, fasilitator pengembangan bakat minat generasi muda, dan pengenalan budaya ke daerah lain. Dari kegiatan tersebut berdampak terhadap kenaikan angka kelompok kesenian yang setiap tahunnya selalu meningkat dan stabil, hal tersebut terwujud karena adanya upaya dari Dinas Pariwisata dan Kebudayaan Kabupaten Ponorogo yang di laksanakan secara konsisten. Selain itu pengenalan budaya lokal ke luar daerah juga menarik wisatawan dari luar untuk mengunjungi Kabupaten Ponorogo guna menyaksikan pagelaran rutin yang di gelar terutama Festival Nasional Reyog Ponorogo. Namun dari upaya yang sudah di lakukan juga terdapat beberapa kesenian lokal yang di ambil dari data Dinas mengalami penurunan jumlah peminat dan pelaku yang semakin sedikit bahkan perlu penanganan khusus.
\end{abstract}

Kata Kunci: pariwisata; pelestarian kesenian; budaya lokal. 


\section{PENDAHULUAN}

Potensi kebudayaan dan kesenian yang ada di Kabupaten Ponorogo merupakan aset yang harus di manfaatkan secara maksimal melalui kepariwisataan Dinas Pariwisata dan Kebudayaan sebagai instansi yang bertanggung jawab menangani perkembangan pariwisata dan pelestarian budaya lokal saat ini sudah berjalan baik. Dinas pariwisata dan kebudayaan sebagai instansi yang bertanggung jawab menangani perkembangan pariwisata dan pelestarian kesenian lokal saat ini sudah melakukan kegiatan guna mewujudkan apa yang sudah menjadi tanggung jawabnya. Program kerja dan program pelestarian budaya dapat berjalan dengan baik dengan adanya kerjasama dinas-dinas yang ada di Ponorogo. Upaya yang sudah dilakukan oleh Dinas Pariwisata Kabupaten ponorogo terkait dengan pelestarian budaya dan kesenian lokal yaitu mengkongkritkan pelayanan publik dalam bentuk programprogram misalnya melalui program pemeliharaan dan pelestarian budaya lokal melalui regulasi, pembuatan museum atau pameran budaya, mengadakan kegiatan rutin pentas budaya. Hal tersebut merupakan langkah konkrit guna pelestarian budaya lokal yang dilakukan oleh dinas pariwisata, sehingga dengan langkah konkrit tersebut bisa meningkatkan perekonomian masyarakat, sekaligus menjaga kearifan lokal. Ini bisa di kaitkan dengan era globalisasi kebudayaan yang bisa mengancam indigenisasi budaya lokal. Di harapkan dengan adanya upaya pengoptimalan promosi serta usaha usaha guna pelestarian budaya lokal oleh Dinas Pariwisata dapat memajukan kegiatan pariwisata Kabupaten Ponorogo serta dapat mendatangkan dan menambah jumlah wisatawan, juga dapat di jadikan sebagai koreksi guna perbaikan dalam bidang sosial dan budaya kearifan lokal.

Kebudayaan merupakan suatu hubungan dari bagian kehidupan masyarakat, yakni seperti cara berperilaku, kepercayaan, tindakan serta hasil dari sebuah aktivitas manusia atau masyarakat yang mempunyai ciri sendiri untuk masyarakat biasa maupun kelompok masyarakat tertentu dan kebudayaan akan terus berkembang seiring dengan hasil dari proses sosialiasi yang ada (Elly M. Setiadi, 2011).

Budaya merupakan sebuah konsep yang memiliki energi untuk membangkitkan minat sedangkan secara formal budaya adalah sebuah tatanan ilmu pengetahuan, kepercayaan, nilai, pengalaman, waktu, hierarki, makna, sikap, konsep alam semesta, hubungan antar ruang, objek materi, dan suatu hak miliki dari kelompok masyarakat yang di peroleh dari hasil turun temurun melalui manusia ataupun kelompok (Warsito, 2015). Sedangkan kesenian merupakan suatu unsur bagian dari budaya yang merupakan suatu wujud ekspresi dari sebuah keindahan untuk pemenuhan kebutuhan jiwanya yang kehadirannya tidak bisa lepas dari kehidupan manusia karena kesenian merupakan suatu wujud kreativitas masyarakat guna menyampaikan gagasan, sebagai sarana komunikasi dan sebagai ajang penyaluran bakat (Lasmawanti, 2013).

Dalam pelaksanaan pelestarian kebudayaan lokal Dinas Pariwisata sudah mengupayakan berbagai hal untuk mendukung pelestarian kebudayaan yang ada di kabupaten ponorogo dengan menggelar agenda kegiatan seni budaya rutin tahunan dan bulanan hal tersebut sudah menjadi program yang terealisasikan pada saat ini. adapun kesenian budaya lokal menurut data yang di peroleh dari dinas pariwata seni kebudayan lokal di Kabupaten ponorogo yang sudah berjalan secara rutin yakni kesenian Reyog Ponorogo, Kesenian Wayang Kulit, Teater Ponorogo, Dalang, Gajah-Gajahan dan yang terahir adalah Kesenian Jaranan Thik hal tersebut menjadi bukti nyata dari peran serta upaya dari dinas pariwisata yang sudah membuktikan dengan sukses dan berjalanya program kerjanya.

Kesenian Reyog Ponorogo merupakan kesenian budaya lokal asli dari ponorogo yang sejarahnya terjadi sebelum Kabupaten ponorogo itu sendiri terbentuk yang kemudian turun temurun tumbuh dan berkembang hingga saat ini yang sudah menjadi hak milik Kabupaten 
Ponorogo. Kesenian reyog merupakan salah satu kebudayaan lokal yang saat ini sedang di lestarikan dari berbagai kebudayaan lainnya yang ada di ponorogo yang sudah di jelaskan pada paragraf sebelumnya.

Pada dasarnya setiap kebudayaan yang akan ditampilkan dan dipertunjukkan perlu kesinambungan yang dapat memberikan urgensi bagi masyarakat terutama Kabupaten ponorogo. Dalam hal ini, sektor kebudayaanlah yang memiliki daya pikat yang tinggi untuk masyarakat. Kebudayaan tersebut dapat di pertunjukkan pada masyarakat umum baik pendatang ataupun wisatawan. Akan menjadikan lapak keuntungan bagi pekerja seninya, tidak hanya sektor pariwisata tetapi dari sektor sumber daya manusianya. Kearifan lokal dapat di lestarikan melalui berbagai pertunjukan, baik yang nasional maupun internasional. Dinas Pariwisata dan Kebudayaan melakukan hal konkit untuk lebih menekankan pada sektor budaya yang sudah dijalankan, respon masyarakat dengan adanya kegiatan pemberdayaan cagar budaya sudah tepat sasaran. Pemberdayaan masyarakat terhadap cinta budaya lokal perlu ditingkatkan guna mencapai tujuan yang lebih baik.

Tingkat sumber daya masyarakat yang mengalami siklus naik turun membawa pengaruh terhadap sektor pariwisata dan budaya. Untuk itu pada saat ini Dinas Pariwisata sudah menjalankan program pelestarian budaya lokal dengan melakukan perbaikan infrastruktur cagar budaya seperti klampis ireng yang sangat bagus pembangunannya, pengadaan pagelaran pentas budaya seni reog malam bulan purnama yang di gelar rutin setiap bulan purnama terjadi, agenda tahunan festival dalang cilik yang bertujuan untuk meningkatkan minat generasi penerus, dan yang paling terbesar adalah pagelaran festival reog nasional setiap tahunnya hal tersebut merupakan salah satu contoh nyata berhasilnya program yang di kerjakan oleh Dinas Pariwisata dan Kebudayaan Kabupaten Ponorogo.

Berdasarkan pada latar belakang masalah diatas, penulis ingin meneliti tentang peran

Dinas Pariwisata dan Kebudayaan dalam upaya pelestarian kesenian budaya lokal di Kabupaten Ponrogo. Dengan demikian peneliti memberikan rumusan masalah yaitu, "Bagaimana peran Dinas Pariwisata dan Kebudayaan dalam pelestarian kesenian lokal yang ada di Kabupaten Ponorogo dan kesenian lokal apa saja yang harus di lestarikan yang ada di Kabupaten Ponorogo. Adapun terkait latar belakang dan sebuah rumusan masalah yang telah dikemukakan diatas dapat ditetapkan tujuan penelitian ini sebagai berikut: tujuannya adalah untuk mengetahui peranan Dinas Pariwisata dan Kebudayaan dalam upaya melestarikan dan menggali potensi budaya lokal yang ada di Kabupaten Ponorogo dan untuk mengetahui bagaimana tahapan-tahapan dan cara kerja yang di lakukan oleh Dinas Pariwisata dan Kebudayaan dalam upaya melestarikan kesenian budaya lokal di Kabupaten Ponorogo.

\section{TINJAUAN PUSTAKA}

Peran merupakan suatu tanggung jawab dimiliki oleh seseorang maupun instansi pemerintah yang bertugas untuk memenuhi kebutuhan dari masyarakat sesuai dengan tugas dan fungsinya. Peran juga merupakan suatu dinamisasi yang terbentuk dari statis maupun penggunaan dari suatu pihak yang mempunyai kewajiban dan biasanya disebut subyektif (Nilam, 2015). Karl \& Rosenzweig mengutarakan bahwa peranan berkaitan mengenai sebuah kegiatan seseorang yang memiliki kedudukan, baik di dalam lingkungan masyarakat maupun dalam suatu organisasi, sehingga dapat disimpulkan jika peranan adalah sebuah suatu perilaku atau tindakan yang berkaitan erat dengan kedudukan dalam sebuah organisasi (Hendro, 2016).

Menurut Blakely Kedudukan dari pemerintah dan perannya dapat mencakup mengenai peran-peran wirausaha, koordinator, fasilitator dan juga stimulator (Alfiyah, 2019). Sedangkan menurut Siagian pemerintah dalam perannya terfokus pada proses 
pembangunan, peran yang di fokuskan pada stabilisator, inovator, dan modernisator(Nilam, 2015).

Menurut Max Weber pemerintah merupakan alat yang digunakan untuk menajalankan suatu peranan hal tersebuat di katakan oleh Max Weber dalam teori birokrasi yang di ungkapkannya dan berbunyi bahwa birokrasi merupakan sebuah alat untuk kekuasaan bagi pemilik yang menguasainya yakni dimana pejabat-pejabat yang mempunyai tujuan yang sama dalam kontinuitasnya. Max Weber mengatakan bahwa untuk mengetahui tipe-tipe birokrasi yang rasional dapat di lakukakan dengan beberapa cara yakni:

a. Pejabat harus bertindak secara rasional dengan di batasi oleh jabatan yang dimiliki.

b. Jabatan di sesuaikan dari tingkatan hierarki yakni dengan susunan dari atas kebawah dan menyamping dan konsekuensinya adalah berupa perbedaan dalam konteks kekuasaan.

c. Secara spesifik masing-masing tugas dan fungsi dari setiap jabatan pasti berbeda.

d. Kontrak jabatan harus dimiliki oleh setiap pejabat dan harus di jalankan.

e. Gaji dan dana pensiun berhak dimiliki oleh setiap pejabat.

f. Jenjang karier terstruktur dan memiliki pengembangan yang jelas.

g. Demi profesionalitas dan kinerja yang bagus setiap pejabat harus di seleksi sesuai dengan kualifikasi yang dimiliki.

h. Pejabat sangat dilarang keras menyalahgunakan jabatan yang dimiliki.

i. Pejabat di haruskan bersifat disiplin dan mentaati peraturan sesuai dengan sistem dan selalu dalam pengawasan (Wakhid, 2011).

Pelaksanaan tugas birokrasi dengan corak lama, pada akhirnya akan menggangu efektifitas kerja pemerintah, hal ini yang kemudian menciptakan patologi birokrasi, yang terlihat dari ketidakefektifan dan juga ketidakefisiensi keberadaan birokrasi, selain itu praktik - praktik kolusi, korupsi, dan nepotisme tumbuh subur, sehingga menyebabkan kinerja pemerintah menjadi terganggu dan bermasalah(Wakhid, 2011).

Peranan pemerintah terlihat dari bekerjanya institusi dengan perangkatnya yakni birokrasi, yang dituntut untuk menjalankan tugas pokok dan fungsi secara professional, sebagai bentuk dari kehadiran Negara terhadap persoalan-persoalan masyarakat, dalam praktiknya birokrasi harus kemudian diharapkan dapat melakukan fungsi-fungsi manajemen dan pelayanan secara baik, konsep birokrasi lama yang terkenal dengan keruwetan dan hirarkis harus bisa diminimalisir (Usman, 2011).

Perbaikan birokrasi yang ada di Indonesia adalah dengan melakukan reformasi, hal ini diarahkan untuk perbaikan dalam tata kelola pemerintahan, sehingga birokrasi yang diinginkan pada abad ke-21 yakni terwujudnya birokrasi yang mampu melakukan penyelenggaraan pemerintahan yang berkelanjutan (sustainable governance) untuk mengemban amanah rakyat (Wakhid, 2011). Hal penting yang menjadi kunci penyelenggaraan pemerintahan yang baik adalah terwujudnya birokrasi yang baik dan professional (Rumzi, 2011). Penyelenggaraan pemerintahan yang baik merupakan perbaikan terhadap berbagai lini yang mencakup: paradigma, idiologi, budaya dan juga manajemen pengelolaan pemerintah supaya dapat meningkatkan kinerja lembaga pemerintahan (Duadji, 2012).

\section{METODE}

Jenis penelitian yang di ambil adalah deskriptif kualitatif yakni objek dari penelitianpenelitian yang diambil menjadikan pengaruh terhadap pertimbangan-pertimbangan yang diambil mengenai jenis pendekatanya, desain maupun metode yang nantinya akan di terapkan. Yang dimaksud pendekatan kualitatif adalah suatu penelitian yang bertujuan untuk untuk menjelaskan secara rinci dengan mendiskripsikan adanya suatu fenomena dari 
aktifitas soaial, peristiwa di masyarakat, sikap masyarakat, kepercayaan, serta persepsi dari pemikiran masyarakat baik secara individu maupun dari kelompok masyarakat. Beberapa objek bahan deskripsi sangat di perlukan guna mendapatkan hasil ahir dan kesimpulan yang nantinya akan di dapat. Sukmadinata mengatakan bahwa peneltian kualitatif adalah bersifat induktif penelitian ini bersifat membiarkan adanya permasalahn-permasalahan dan di biarkan terbuka untuk di interpretasikan. Data yang di dapatkan lalu di kumpulkan dengan melakukan pengamatan yang benar-benar akurat, yang didalamnya mencakup tentang deskripsi dengan disertai konsep yang sangat detail dengan di sertakan hasil dari wawancara dengan data penguat lainnya yakni hasil dari analisis dokumen dan catatancatatan yang valid (Bachri, 2010).

Penelitian ini dilaksanakan tepatnya di kantor Dinas Pariwisata dan Kebudayaan Kabupaten Ponorogo yang beralamatkan di Jln. Pramuka, No.19A, Kabupaten Ponorogo, Telepon (0352) 4860 penelitian ini dilakukan yang terfokus pada bidang kebudayaan khususnya dalam pengembangan dan pelestarian kebudayaan lokal di kabupaten Ponorogo dengan tujuan yang jelas, sasaran, kebijakan dan strategi yang jelas yang paling utama adalah tujuan guna menggali potensi dan melestarikan kebudayaan lokal yang ada serta menumbuhkan kesadaran dan mengikutsertakan masyarakat dalam berpartisipasi pengembang budaya lokal tersebut di kabupaten ponorogo. Yang melatar belakangi penentuan objek penelitian ini adalah sejauhmana program yang sudah di lakukan dan bagaimana pengaruhnya terhadap tingkat pemahaman serta kesadaran generasi muda terhadap kebudayaan lokal yang ada di kabupaten Ponorogo, penulis mengambil lokasi penelitian karena terkait dengan bagaimana peran Dinas Pariwisata untuk menjaga eksistensi kebudayaan lokal di wilayah Ponorogo, ini menyangkut program - program atau rencana strategis yang sudah dilakukan.

Metode dokumen sama arti dengan teknik dokumentasi yakni pengumpulan data dengan melalui informasi dari hasil pencarian dan bukti-bukti temuan. Metode dari teknik dokumentasi ini merupakan sebuah metode dari cara-cara pengumpulan data yang di hasilkan dari sumber sumber elektronik juga arsip-arsip yang disimpan oleh Dinas Pariwisata dan Kebudayaan yakni sebuah catatan dari peristiwa ataupun kejadian yang sudah berlalu dokumen tersebut bisa berbentuk tabel, grafik, gambar dan tulisan. Dalam isi dari penelitian ini dokumen yang dicantumkan adalah berupa foto dari hasil kegiatan dan program kesenian yang sudah dilaksanakan. Wawancara merupakan teknik dari pengumpulan data dengan mendapatkan keterangan-keterangan melalui cara langsung bertanya kepada responden. Wawancara tersebut dilakukan guna mendapat dan mengumpulkan data sosial dengan tujuan untuk mencari tau bagaimana tanggapan, pendapat dan keyakinan dari para responden. Wawancara berfungsi untuk menggali sebuah teknik dari cara mengumpulkan data kemudian apabila peneliti ingin melaksanakan sebuah program untuk studi pendahuluan dan digunakan guna menentukan permasalahan yang di teliti dengan lebih mendalam dan jumlah responden yang lebih kecil (Sugiyono, 2010).

Praktik pengumpulan data dilakukan melalui wawancara dan juga dokumentasi, disini peneliti memilih beberapa informan yang mengetahui seluk-beluk program dinas yang dijalankan dalam rangka melestarikan kebudayaan lokal, infromasi yang di himpun berupa hasil wawancara dan dokumentasi terkait persoalan yang dikaji.

\section{HASIL DAN PEMBAHASAN}

\section{Profile Potensi Kebudayaan Lokal}

Potensi kesenian tradisional dan budaya lokal di kabupaten ponorogo yakni Kesenian Reog berjumlah 392, Kesenian Gajah-Gajahan berjumlah 80, Kesenian Musik Lokal Odrot berjumlah 14, Kesenian lokal Kongkil berjumlah 9, Karawitan berjumlah 16, 
Jaranan Thik berjumlah 63, Sinden berjumlah 24, Kesenian Keling berjumlah 1, Kesenian Ketoprak berjumlah 30, Wayang Kulit berjumlah 19, Kesenian Ludruk berjumlah 10, Kesenian Dongkrek berjumlah 4, Kesenian Unto-Untonan berjumlah 7, dan Sanggar Tari berjumlah 30 sanggar (sumber: Data diolah dari hasil penelitian).

Dari data jumlah tersebut dapat disimpulkan bahwa jumlah tertinggi masih diduduki oleh kesenian Reyog Ponorogo yang mana kesenian tersebut merupakan asli dari Ponorogo yang sudah di kenal di kancah nasional dan internasional. Sedangkan jumlah terendah menurut data di miliki oleh kesenian keling yang hanya ada di desa singgahan dan asli dari desa singgahan pulung kesenian keling merupakan sebuah tarian yang dilakukan oleh laki-laki yang seluruh wajah dan tubuhnya di cat hitam, untountonan merupakan kesenian yang terinspirasi dari budaya arab berasal dari desa cekok berupa adanya hewan unta mainan serta diiringi oleh penari berbaju gamis arab dan musik sholawatan jawa, kongkil merupakan kesenian alat musik terbuat dari bambu yang berasal dari bungkal ponorogo kesenian kongkil biasanya di mainkan oleh 8-10 orang kongkil sendiri memiliki bentuk seperti angklung namun di gantungkan berjajar dan di jadikan satu, dan yang terahir dongkrek merupakan dongeng rakyat yang di perankan dengan menggunakan topeng yang khas dan baju tradisional.

\section{Peran Dinas Pariwisata dan Kebudayan Kabupaten Ponorogo}

Peran Dinas Pariwisata dan Kebudayaan Kabupaten Ponorogo merupakan komponen penting sebagai alat kontrol dalam mengatur berjalannya program dan upaya pelestarian kebudayaan lokal dimana kegiatan pendampingan dan penyusunan berbagai acara pagelaran kesenian rutin dan festival-festival sampai saat ini sudah di jalankan dengan baik. Keikutsertaan berbagai paguyuban seni seperti kesenian Reyog, Musik Lokal, Karawitan, Jaranan Thik, Sinden, Dalang, Wayang Kulit, Sanggar Tari dan juga pembibitan generasi penerus kesenian lokal merupakan usaha dari upaya pelestarian budaya lokal yang di programkan oleh Dinas Pariwisata dan Kebudayaan. Terutama penanganan angka kritis dari peminat kesenian Keling, unto-untonan, kongkil dan dongkrek upaya pendampingan terus di lakukan guna memantau perkembangan dan upaya meningkatkan jumlah peminat. Meskipun jumlah kesenian kurang peminat namun Dinas Pariwisata dan Kebudayaan selalu berupaya untuk mengadakan festifal dengan tetap menampilkan kesenian tersebut sebagai upaya mempertahankan dan menarik minat masyarakat.

\section{a. Sumber Daya Manusia Birokrasi}

Sumber Daya Manusia khusunya dalam Dinas Pariwisata dan Kebudayaan merupakan seluruh manusia yang ada dalam organisasi tersebut dan menjalankan tugasnya masing-masing guna mencapai target dari apa yang sudah di programkan. Hal itu sangat berhubungan erat dengan kualitas Sumber Daya Manusianya yang harus memenuhi syarat dan ketentuan yang ada, di tinjau dari pengalaman kerja dan tingkat pendidikan pendidikan sudah memenuhi syarat yakni S3 1 Orang, S2 3 Orang, S1 9 Orang, D3 12 Orang, dan SMA 9 Orang. Setiap bidang selalu mempunyai staf yang ahli dan sesuai dengan bidang serta pendidikan terahir yang di miliki klasifikasi tersebut dilakukan dengan maksud dan tujuan supaya tidak keluar dari jalur dan sesuai pada bidang keahlian yang dimiliki dengan begitu program kinerja akan berjalan dengan maksimal. Dinas Pariwisata dan Kebudayaan juga mempunyai rasa solidaritas yang tinggi sehingga kinerja yang baik dan berkualitas akan terus tercipta dan program pelestarian budaya lokal akan berjalan sesuai yang di harapkan. 


\section{b. Sarana dan Prasarana Penunjang}

Sarana dan prasarana guna penunjang program pelestarian kebudayaan juga sudah tersedia dan di fasilitasi oleh Dinas Pariwisata dan Kebudayaan seperti alat musik tradisional, kostum dan gedung kesenian dimana fasilitas tersebut dapat digunakan oleh siapapun yang berkepentingan dalam tujuan pelestarian budaya lokal. Fasilitas tersebut dirasa sudah sangat bagus tinggal bagaimana upaya dari pihak Dinas Pariwisata dan Kebudayaan agar fasilitas tersebut dan bermanfaat bagi masyarakat dan tepat pada sasaran. fasilitas yang harus ada pada setiap organisasi baik pemerintah maupun non pemerintah guna menunjang aktivitas yang ada di dalamya dan sebagai alat penunjang program kerja yang sedang di jalankan dalam hal ini sarana dan prasarana yang dimiliki oleh Dinas Pariwisata dan Kebudayaan harus mengacu pada fungsinya sebagai alat untuk menjaga agar kebudayaan lokal dapat tetap lestari dan terjaga peran yang tidak kalah penting lainnya yakni pada saat pagelaran pentas kesenian secara langsung melibatkan masyarakat untuk ikut serta berpartisipasi dalam kegiatan sehingga dapat menumbuhkan kecintaan dan antusiasme masyarakat terhadap budaya lokal. Untuk fasilitas penunjang berupa gamelan, gong dan seperangkatnya biasa digunakan saat acara pentas reog guna memfasilitasi para penari. Sejauh ini Dinas Pariwisata dan Kebudayaan baru menyediakan seperangkat alat gamelan, gong, dan angklung yang berjumlah kurang lebih 50 buah. Adapun ketentuan yang berlaku dalam penggunaan fasilitas yang ada yakni untuk tetep menjaga kebersihan dan merawat dengan baik saat digunakan sampai selesai.

Upaya menggali potensi pada generasi penerus oleh Dinas Pariwisata dan Kebudayaan dilakukan dengan penyelenggaran pagelaran budaya lokal dijadikan sebagai sarana sosialisasi untuk menarik minat masyarakat terhadap adanya budaya lokal diwilayah mereka dampak nyata bisa kita lihat dari keterlibatan masyarakat mulai dari anak-anak di buktikan pada saat pagelaran banyak peserta yang masih muda namun sudah tampil dengan baik dan antusiasme juga terlihat. Dinas Pariwisata dan Kebudayaan juga selalu melakukan bimbingan dan kerja sama dengan selalu menggelar komunikasi rutin dengan sesepuh ahli seni yang ada di Kabupaten Ponorogo. Upaya lain dengan menarik minat melalui pameran event budaya yang terahir dilakukan dengan peserta seluruh jawa timur yang di gelar bulan oktober tahun 2018. Jadi dapat di simpulkan kegiatan promosi dalam hal upaya menarik minat dan menggali potensi yang dilakukan oleh Dinas Pariwisata dan Kebudayaan tidak hanya terfokus pada kegiatan festival dan sosialisasi namun dapat memanfaatkan berbagai kesempatan untuk mengenalkan budaya lokal asli Ponorogo kepada masyarakat dengan cara-cara yang di sebutkan di atas juga memanfaatkan peluang yang ada dengan kreativitas yang dimiliki staf Dinas Pariwisata dan Kebudayaan bekerjasama dengan masyarakat yang manfaatnya akan kembali pada masyarakat.

\section{Keberhasilan Program Pemerintah}

Guna keberhasilan program di tahap perencanaan khususnya pada bidang kebudayaan merencanakan program kerjanya yang sebagai kegiatan penunjangnya tercantum pada form daftar kegiatan penunjang pelestarian budaya lokal Kabupaten Ponorogo tahun 2018-2019 point pertama mengenai jalin mitra bersama dengan dinas terkait seluruh Jawa Timur guna meningkatkan minat dan kesadaran masyarakat tentang pentingnya kebudayaan lokal. Dengan kegiatan tersebut diharapakan seluruh masyrakat baik Kabupaten Ponorogo sendiri khususnya maupun masyarakat luar dan 
birokrasi pemerintah dapat bersinergi guna keberhasilan program yang dijalankan Dinas Pariwisata dan Kebudayaan Kabupaten Ponorogo.

Pencapaian sebuah program kerja tidak akan berjalan dengan baik apabila mekanisme koordinasi dari organisasinya sendiri tidak berjalan dengan lancar maka dari itu Dinas Pariwisata dan Kebudayaan sangat mengutamakan leadership. Pentingnya berkomunikasi dan berkoordinas sangat di junjung tinggi oleh para pegawai dengan atasan maupun sebaliknya sehingga tugas serta tanggung jawab yang harus di selesaikan dapat di selesaikan bersama-sama, koordinasi dapat dijadikan sebagai sinergi dalam organisasi itu sendiri.

Kegiatan yang sudah dilaksanakan dalam bentuk pentas kesenian sebagai wujud nyata dari program pelestarian budaya lokal dari tahun 2018-2019 yakni Pentas Reyog Bulan Purnama, Pentas Wayang Kulit, Pentas Reyog Telaga Ngebel, Pentas Seni Teater, Pentas Dongeng Reyog Anak, Festival Dalang Bocah, Festival Topeng Internasional, Reyog Jazz, Festival Reyog Mini, Pentas Seni Rakyat Gajah-Gajahan, Pentas Jaranan Thik, dan Gebyar Jathil Masal. Kegiatan tersebut dilakukan sebagai aksi sosialisasi kepada masyarakat dan memperkenalkan potensi budaya apa saja yang dimiliki Kabupaten Ponorogo kepada generasi muda bersama-sama berperan aktif mengikuti acara pagelaran budaya. Tujuan utama dari acara tersebut yakni mendorong kemudian memberikan wadah bagi masyarakat Kabupaten Ponorogo untuk dapat berperan aktif mengikuti kegiatan upaya Pelestarian Budaya Lokal.

Berbagai acara dan kegiatan festival yang selalu rutin di jalankan di Kabupaten Ponorogo secara tidak langsung memberikan fasilitas dan wadah bagi masyarakat serta remaja berupa kegiatan festival reog mini, dalang bocah dan pentas budaya malam bulan purnama yang selalu melibatkan masyarakat dengan pengisi acara di ambil dari setiap kecamatan dan dilakukan secara bergilir. Dengan adanya kegiatan tersebut diharapkan apresiasi dan keikutsertaan remaja beserta masyarakat dapat tertuang dalam agenda kegiatan rutin tahunan yang selalu di gelar tersebut.

Guna menjaga kelestarian budaya lokal staf Dinas Pariwisata dan Kebudayaan Kabupaten Ponorogo di tuntut untuk selalu berperan aktif dalam memberikan inovasiinovasi baru, memantau dan mengevaluasi secara langsung keberlangsungan program yang di jalankan, serta memberikan pengawasan dan pendampingan kepada masyarakat sebagai upaya dan dukungan penuh dari Dinas Pariwisata dan Kebudayaan terhadap keberlangsungan kelestarian budaya lokal di kabupaten Ponorogo. Adapun upaya membangun mitra dengan pihak swasta juga sangat di perlukan.

Upaya promosi selalu dilakukan seperti yang tertera dalam kegiatan penunjang pelestarian budaya lokal Tahun 2018-2019. Upaya-upaya tersebut selalu gencar di laksanakan dengan harapan kebudayan lokal di Kabupaten Ponorogo akan terus berkembang di kemudian hari dan selalu beregenerasi sehingga dapat di nikmati oleh anak cucu generasi penerus supaya nantinya dapat dijadikan sebagai ciri khas maupun karakter daerah. Dengan memanfaatkan sosial media yakni dengan cara meliput berbagai kegiatan pentas kesenian lokal kemudian di unggah dalam situs internet dengan harapan masyarakat luas dapat melihat tertarik dan ingin mengenali yang berdampak terhadap sektor wisata juga pengenalan budaya daerah. Adapun juga upaya promosi lain salah satunya seperti di lakukannya jalin mitra.

Untuk mendapatkkan hasil yang baik dari program pelestarian kebudayaan lokal selalu dilakukan pendampingan dalam hal perencanaan , proses pelaksanaan hingga hasil yang di capai untuk bisa digunakan sebagai koreksi dalam meninjau seberapa berhasil program yang di jalankan dan apabila menemui suatu masalah supaya dapat segeran diselesaikan dan dijadikan bahan pertimbangan untuk kelangsungan program 
yang akan dijalankan nantinya. Hal tersebut berkaitan dengan 4 teori pengembang budaya yang di kemukakan oleh Abdul Rachman Patji yakni:

1. Pengembangan nilai dilakukan program-program guna meningkatkan pemahaman terhadap budaya lokal guna menumbuhkan kesadaran masyarakat dengan tujuan seluruh lapisan masyarakat dapat menjaga dan mengimplementasikan warisan budaya leluhur.

2. Pengembangan teknis yakni terfokus pada sarana dan prasarana. Fasilitasi perlengkapan kesenian, sanggar dan lainya serta penggunaan yang tepat pada sasaran.

3. Pengembangan sosial yakni mengelola seluruh potensi kebudayaan lokal yang ada terutama pada usia remaja.

4. Pengembangan budaya daerah, melalukan tindakan dan aksi guna mensosialisasikan program yang sedang dijalankan kepada masyarakat dengan tujuan program dapat tepat sasaran dan sesuai dengan apa yang sudah di rencanakan (Patji, 2010).

Dari ke empat teori di atas Dinas Pariwisata dan Kebudayaan Kabupaten Ponorogo dalam realisasi programnya sudah memenuhi dari ke empat unsur teori diatas. Hal tersebut dapat dilihat melalui hasil wawancara yang di peroleh dari staf Dinas Pariwisata dan Kebudayan juga hasil wawancara kepada masyrakat umum. Dan untuk hasil program yang sudah dijalankan keseluruhannya sebagian besar mendapat respon yang baik dari masyarakat umum. Hal tersebut membuktikan bahwa antusias dari masyarakat Kabupaten Ponorogo terhadap kebudayaan lokal daeranya masih tergolong tinggi. Dalam hal ini yang menjadi point penting adalah bagaimana nantinya hal apa yang dilakukan lebih lanjut guna terciptanya rasa akan pentingnya pemahaman kesadaran dalam menjaga kelestarian budaya lokal khusunya di Kabupaten Ponorogo.

\section{KESIMPULAN}

Peran Dinas Pariwisata dan Kebudayaan nampak dari upaya-upaya yang dilakukannya, sehingga kebudayaan lokal di Kabupaten Ponorogo masih terus bertahan atau eksistensi nya tetap ada. Tiga jenis kesenian yang pada saat ini berada pada penanganan yang serius oleh Dinas Pariwisata dan Kebudayaan yang pertama adalah keling yang hanya ada di desa singgahan dan merupakan kebudayaan asli dari desa singgahan pulung kesenian keling merupakan sebuah tarian yang dilakukan oleh laki-laki dengan seluruh wajah dan tubuhnya di cat hitam, kedua adalah unto-untonan yaitu kesenian yang terinspirasi dari budaya arab berasal dari desa cekok dengan ciri khas adanya hewan unta mainan dan di iringi oleh penari berbaju gamis arab dan musik sholawatan jawa, dan ke tiga kongkil yaitu berupa kesenian alat musik terbuat dari bambu yang berasal dari bungkal ponorogo kesenian kongkil biasanya di mainkan oleh delapan sampai sepuluh orang kongkil sendiri memiliki bentuk seperti angklung namun di gantungkan berjajar dan di jadikan satu. Perlu adanya jadwal penyuluhan bergilir terkait sosialisasi rasa kecintaan terhadap budaya, keseluruh pelosok Ponorogo, selain itu perlu adanya penambahan fasilitas alat musik kesenian guna penunjang untuk masyarakat supaya menjadi lebih bersemangat dan tidak akan ada masalah lagi mengenai kendala kurangnya peralatan kesenian.

\section{UCAPAN TERIMA KASIH}

Saya mengucapkan terima kasih kepada Kantor Dinas Pariwisata dan Kebudayaan Kabupaten Ponorogo atas ijin dari kegiatan penelitian yang telah saya lakukan di instansi tersebut. Saya juga mengucapkan terima kasih kepada Almamater Program Studi Ilmu Pemerintahan, Fakultas Ilmu Sosial dan Ilmu Politik, Universitas Muhammadiyah Ponorogo. 


\section{DAFTAR RUJUKAN}

Alfiyah, N. I. (2019). Pengaruh Penerapan e-Government Pada Pembangunan Smart City di Kabupaten Sumenep. Jurnal Inovasi Ilmu Sosial Dan Politik (JISoP), 1(2), 88-95. https://doi.org/10.33474/jisop.v1i2.4800

Bachri, B. S. (2010). Meyakinkan Validitas Data Melalui Triangulasi Pada Penelitian Kualitatif. Teknologi Pendidikan, 10(1), 46-62. Retrieved from http://yusuf.staff.ub.ac.id/files/2012/11/meyakinkan-validitas-data-melaluitriangulasi-pada-penelitian-kualitatif.pdf

Duadji, N. (2012). Good Governance dalam Pemerintah Daerah. MIMBAR, Jurnal Sosial Dan Pembangunan, 28(2), 201-209. https://doi.org/10.29313/mimbar.v28i2.356

Elly M. Setiadi, U. K. (2011). Pengantar Sosiologi: pemahaman fakta dan gejala permasalahan sosial; teori, aplikasi, dan pemecahannya. Surabaya: Kencana.

Hendro. (2016). Peranan Kepemimpinan Camat Dalam Meningkatkan Tugas dan Fungsi Pegawai di Kantor Camat Kayan Kabupaten Malinau. EJournal Pemerintahan Integratif, 4(2), 342-353. Retrieved from http://ejournal.pin.or.id/site/wpcontent/uploads/2017/01/05 hendro (01-23-17-02-13-00).pdf

Lasmawanti, P. U. (2013). Tari Cepet Pada Upacara Ngabungbang di Kampung Waluran Desa Gunung Batu Kecamatan Ciracap Kabupaten Sukabumi. Universitas Pendidikan Indonesia.

Nilam, S. P. (2015). Peran Dinas Kebudayaan dan Pariwisata dalam Pengembangan Budaya Daerah di Kabupaten Malinau. E-Journal Pemerintah Integrative, 3(4), 570-582.

Patji, A. R. (2010). Pengembangan Dan Perlindungan Kekayaan Budaya Daerah: Respon Pemerintah Indonesia Terhadap Adanya Klaim Oleh Pihak Lain. Jurnal Masyarakat \& Budaya, 12(3), 167-188. https://doi.org/http://dx.doi.org/10.14203/jmb.v12i3.156

Rumzi, S. (2011). Reformasi Birokrasi. Jurnal FISIP UMRAH, 2(2), 172-182.

Sugiyono. (2010). Metode Penelitian Pendidikan (Pendekatan Kuantitatif, kualitatif dan $R$ \& D). Bandung.

Usman, J. (2011). Manajemen Birokrasi Profesional Dalam Meningkatkan Pelayanan Publik. Otoritas: Jurnal Ilmu Pemerintahan, 1(2), 102-109. https://doi.org/10.26618/ojip.v1i2.24

Wakhid, A. A. (2011). Eksistensi Konsep Birokrasi Max Weber Dalam Reformasi Birokrasi Di Indonesia. Jurnal TAPIs, 7(2), 125-146. Retrieved from http://ejournal.iainradenintan.ac.id/index.php/TAPIs/article/view/100

Warsito. (2015). Antropologi Budaya. Yogyakarta: Ombak. 